\title{
ASSESSMENT OF HEAVY METAL POLLUTION IN THE LUPA GOLD FIELD, SW TANZANIA
}

\author{
SR Mnali \\ Department of Geology, University of Dar es Salaam \\ P.O. Box 35052, Dar es Salaam, Tanzania
}

\begin{abstract}
The concentrations of As, Cd, Cr, Cu, Hg and Pb were determined in water, stream sediments, soil, and mine tailings from Lupa Gold Field (LGF), SW Tanzania, in order to assess their pollution levels. As, $\mathrm{Cd}$ and $\mathrm{Cr}$ were determined by automated Graphite Furnace Absorption Spectrophotometry. $\mathrm{Cu}$ and $\mathrm{Pb}$ were analysed by Air-Acetylene Flame, while $\mathrm{Hg}$ was analysed by Cold Vapour Atomic Absorption Spectrophotometry. The mean concentrations obtained were: As: $0.44 \mathrm{ppb}$ (water), $1.2 \mathrm{ppm}$ (sediments), $0.44 \mathrm{ppm}$ (soil) and $5.2 \mathrm{ppm}$ (tailings); $\mathrm{Cd}: 0.03 \mathrm{ppb}$ (water), $0.03 \mathrm{ppm}$ (sediments), $0.03 \mathrm{ppm}$ (soil) and $0.50 \mathrm{ppm}$ (tailings); Cr: $1.4 \mathrm{ppb}$ (water), $70 \mathrm{ppm}$ (stream sediments), $250 \mathrm{ppm}$ (soil) and $270 \mathrm{ppm}$ (tailings); Cu: $30 \mathrm{ppb}$ (water), $68 \mathrm{ppm}$ (sediments), $66 \mathrm{ppm}$ (soil) and $455 \mathrm{ppm}$ (tailings); Hg: $0.25 \mathrm{ppb}$ (water), $1.1 \mathrm{ppm}$ (sediments), $0.10 \mathrm{ppm}$ (soil) and $8.70 \mathrm{ppm}$ (tailings) and $\mathrm{Pb}: 0.50 \mathrm{ppb}$ (water), $85 \mathrm{ppm}$ (sediments), $22 \mathrm{ppm}$ (soil) and $275 \mathrm{ppm}$ (tailings). Leaching of As-based mineral flotation reagents as well as the decomposition of accessory As minerals such as arsenopyrite ( $\mathrm{FeAsS})$, enargite $\left(\mathrm{Cu}_{3} \mathrm{AsS}_{4}\right)$ and tennantite $\left(\mathrm{Cu}_{12} \mathrm{As} \mathrm{s}_{4} \mathrm{~S}_{13}\right)$ most likely contributed to some high As concentrations in the mine tailings. The low Cd content in all samples reflects the low content of sphalerite (in which $\mathrm{Cd}$ replaces $\mathrm{Zn}$ ) typical of the $L G F$ ores. Cromium was low in water, most likely because of its low mobility; it was high in soils and tailings derived from mafic-ultramafic rocks. High $\mathrm{Cu}$ levels in tailings came from dissolution of chalcopyrite and bornite. Neutral to alkaline $\mathrm{pH}$ conditions (6.5-8.5) of water was most likely responsible for its low $\mathrm{Cu}$ levels. Amalgamation of Au concentrate likely introduced $\mathrm{Hg}$ into the environment. Dissolution of galena and anglesite was likely the source of $\mathrm{Pb}$ into the soils, sediments and tailings. The range of concentrations of the six heavy metals recorded in the Lupa gold field is of great concern to the human health.
\end{abstract}




\section{INTRODUCTION}

The Lupa Gold Field (LGF) is the second largest gold producing area in Tanzania after the Lake Victoria Gold fields (Fig. 1). It occupies a total area of about $3,000 \mathrm{~km}^{2}$. It has produced more than 30 tonnes of gold and 8 tonnes of silver since its discovery in 1922 . These precious metals have been produced from artisanal, small- and large-scale surface and underground workings of the gold-quartz reefs that were emplaced in the shear zones that crosscut the gneisses, metamafic rocks and granitoids of the Palaeoproterozoic Ubendian Belt (Fig. 2). Gold and silver were also won from working of alluvial, eluvial and deluvial placer deposits. The ore minerals in the gold-quartz veins comprise principally sulphides (pyrite, chalcopyrite, galena, and traces of sphalerite, molybdenite, pyrrhotite and pentlandite). Other ore minerals include tellurides (altaite, hessite, calaverite, petzite, montanite and melonite), magnetite, tetrahedrite-tennantite, arsenopyrite, electrum and native gold (Mnali 1999).

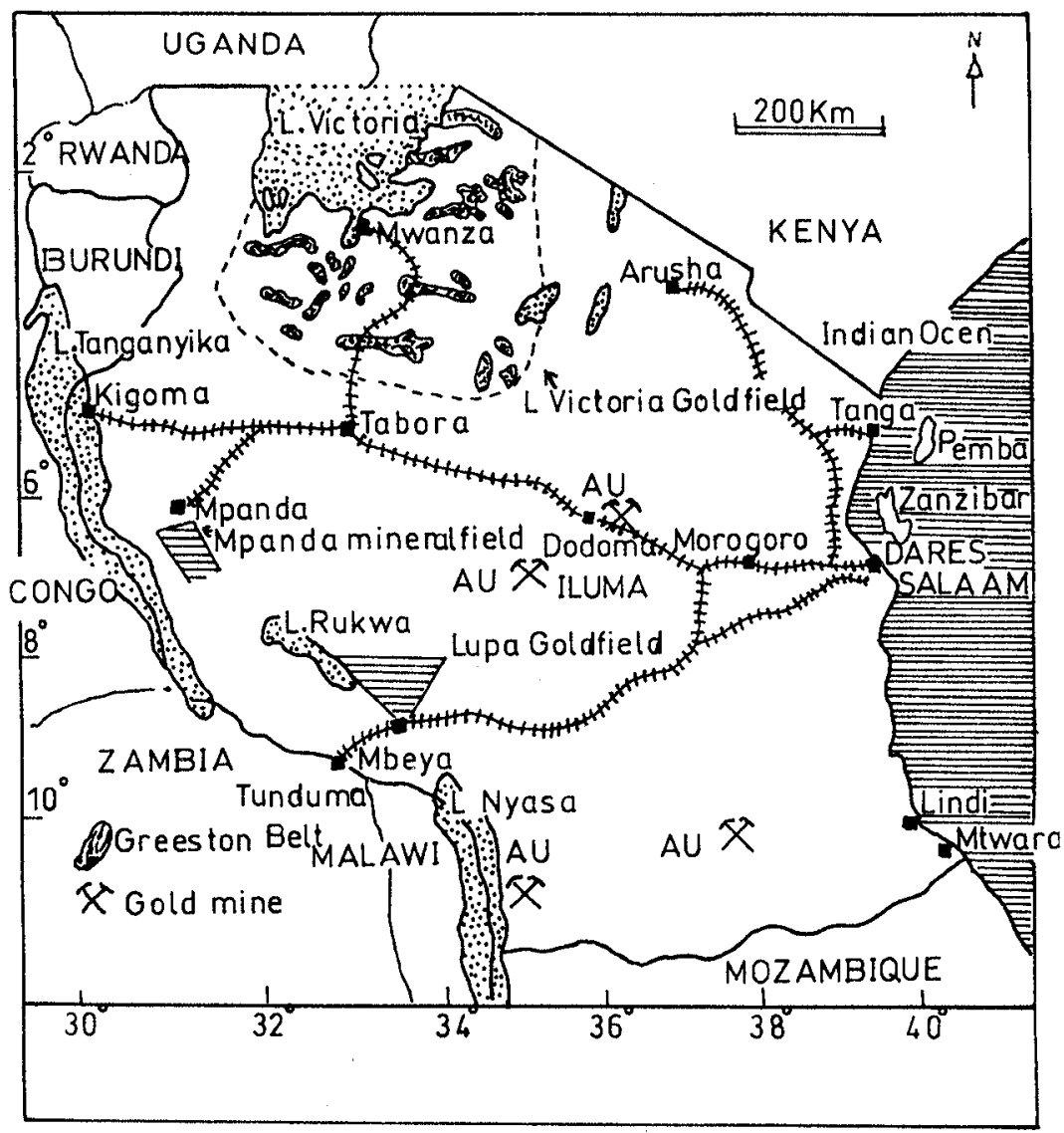

Fig. 1: Map of Tanzania showing major gold producing areas 
The concentrations of $\mathrm{As}, \mathrm{Cd}, \mathrm{Cr}, \mathrm{Cu}, \mathrm{Hg}$ and $\mathrm{Pb}$ were determined in water (45 samples), stream sediments (50 samples), soil (40 samples) and mine tailings (35 samples) from the LGF. These elements were of interest because $\mathrm{Cu}, \mathrm{Pb}$, and $\mathrm{As}$ are found in gold-quartz veins in the study area. Therefore their dissolution could lead to significant anomalies in soils, stream sediments, tailings and water within the Lupa gold field. Cr could originate from weathering of mafic-ultramafic rocks (amphibolites, gabbro and pyroxenites) that constitute the wall rocks for gold-quartz veins. $\mathrm{Cd}$ is commonly associated with sphalerite $(\mathrm{ZnS})$ in which it replaces $\mathrm{Zn}$. The sphalerite occurs in trace amounts in several mines in the study area. Small-scale and artisanal miners use $\mathrm{Hg}$ for the recovery of gold from ore concentrate. The $\mathrm{Hg}$ could therefore enter the environment during amalgamation process and firing of $\mathrm{Au}-\mathrm{Hg}$ amalgam in order to expel $\mathrm{Hg}$.

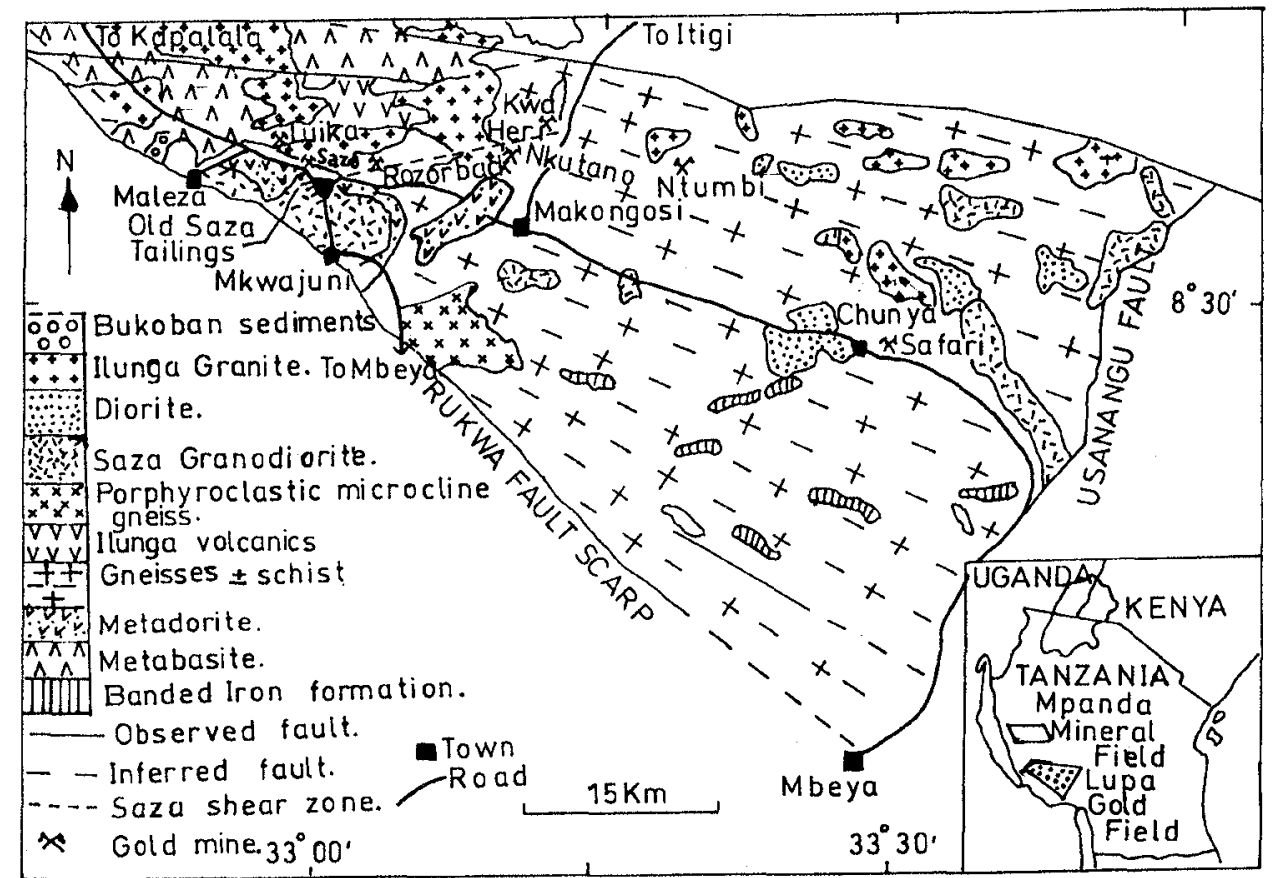

Fig. 2: Geological Map of Lupa gold field, Tanzania, showing gold mines

Health hazards caused by heavy metal pollution have been discussed by Aswathanarayana (1995), Kauranne and Silanpää (1992), Nakamura et al. (1988), Anon. (1993), Berkman and Ryall (1982), and Hopps et al. (1974). Arsenic compounds are toxic and possibly carcinogenic, but the element may also be a nutrient (Kauranne \& Silanpää 1992). Health effects caused by arsenic may include peripheral neuropathy, tubular dysfunction, cirrhosis, anaemia, ulcers, emphysema and fibrosis, skin and lung cancer and chromosomal aberrations (Aswathanarayana 1995). Cadmium is harmful to 
animals because it becomes incorporated in certain low molecular weight proteins of the blood plasma. Cadmium intake might cause tubular, glomerular damage, proteinuria, slight anaemia, emphysema, osteomalacia, cardiovascular diseases, cancer of the prostate gland and lung and chromosomal aberrations. Excessive intake of cadmium has been associated with itai-itai disease in Japan (Kolyjonen 1992), and degeneration of kidney and bones (Aswathanarayana 1995). Chromium is an essential trace nutrient that takes part in the metabolism of glucose. It is poisonous when in hexavalent $\left(\mathrm{Cr}^{6+}\right)$ state. It induces skin sensitisation (Berkman \& Ryall 1982). Impaired glucose tolerance in some human beings can be caused by $\mathrm{Cr}^{3+}$. Copper is an essential micronutrient for all organisms but toxic when in excess. It is responsible for fungal and bacterial resistance in plants. However it may cause staining of laundry and sanitary ware if its concentration in water is above $2 \mathrm{mg} / \mathrm{l}$ (Anon. 1993).

This paper evaluates heavy metal concentrations in various secondary dispersion media (in order to determine pollution levels) resulting from eight decades of uncontrolled gold mining in the LGF.

\section{METHODS}

Soil, stream sediment, water samples and mine tailings were collected during the fieldwork in April 1996. Soil samples were collected from gold mining and amalgamation sites and areas away from mining and processing sites in order to get background concentrations of heavy metals. Stream sediments were collected from streams with flowing water upstream and downstream of gold washing areas, and from small dry streams and tributaries that provided samples for the determination of background concentrations of the heavy metals. Mine tailings were taken from old tailing mounds at Saza, Kwa Heri, and Ntumbi mines; and from current small-scale mines including Safari, Razorback, Nkutano and other artisanal workings within the LGF. Water samples were taken from rivers and streams upstream and downstream of gold washing and amalgamation sites.

Soil, stream sediment and tailing samples were dried and sieved through a clean $250-\mu \mathrm{m}$-mesh size. Two hundred to three hundred milligrams of the resultant fine-fraction were leached with $3 \mathrm{ml}$ of concentrated $\mathrm{HNO}_{3}$ under pressure and temperature of $160^{\circ} \mathrm{C}$ for four hours in a special bomb (Uhrberg 1982), before the solution was made up to $10 \mathrm{ml}$ on cooling. As, $\mathrm{Cd}$ and $\mathrm{Cr}$ were analysed using automated Graphite Furnace Atomic Absorption Spectrophotometry (GFAAS). $\mathrm{Cu}$ and $\mathrm{Pb}$ were analysed by direct aspiration into an Air-Acetylene Flame (FAAS) using titrisol standards. Analytical precision was determined by carrying out duplicate analysis after every 10 samples. Reagent blanks and standard samples were included in each analytical batch to check the analytical error. $\mathrm{Hg}$ was analysed by Cold 
Vapour Atomic Absorption Spectrophotometry (CVAAS) after aspiration with $2 \% \mathrm{SnCl}_{2}$ using the method of standard addition.

The water samples were filtered through $0.45 \mu \mathrm{m}$ membrane filter immediately after collection. The filtered water was divided into two aliquots each containing $100 \mathrm{ml}$. The first aliquot was poured into an acid-washed plastic bottle and $1 \mathrm{ml}$ of super-pure concentrated nitric acid was added. The bottle was then tightly stoppered and labelled. This sample was used for the analysis of $\mathrm{As}, \mathrm{Cd}, \mathrm{Cr}, \mathrm{Cu}$ and $\mathrm{Pb}$. The second aliquot of the sample was poured into the acid-washed clear plastic bottle and $1 \mathrm{ml}$ of concentrated nitric acid and 1 $\mathrm{ml}$ of $5 \%$ potassium dichromate solution were added for preservation purposes (Hamlin 1989). The sample bottle was also stoppered and labelled and used for the analysis of total mercury. The water samples were aspirated directly from the sample bottles and analysed for the heavy metals following the methods described above.

\section{RESULTS}

Very few soil samples contain high concentrations of the heavy metals than the permissible WHO (1993) levels (Table 1). Some stream sediments and mine tailings contained high concentrations of heavy metals above WHO (1993) permissible levels. Water samples contained very low concentrations of the heavy metals.

Table 1. Concentration range (1), arithmetic mean (2), and standard deviation (3) of heavy metals in the various sampling media from the Lupa gold field, Tanzania. The WHO (1993) permissible levels are given as (4)

\begin{tabular}{|c|c|c|c|c|c|c|c|}
\hline $\begin{array}{c}\text { SAMPLE } \\
\text { TYPE }\end{array}$ & & $\overline{\mathrm{As}}$ & $\overline{C d}$ & $\mathrm{Cr}$ & $\overline{\mathrm{Cu}}$ & $\overline{\mathbf{P b}}$ & $\mathrm{Hg}$ \\
\hline Soil & 1) & $0.38-0.70$ & $0.01-0.10$ & $70-900$ & $15-200$ & $10-80$ & $0.05-0.11$ \\
\hline (ppm) & 2) & 0.44 & 0.03 & 250 & 66 & 22 & 0.10 \\
\hline \multirow[t]{2}{*}{$N=40$} & 3) & 0.5 & 0.02 & 180 & 60 & 16 & 0.02 \\
\hline & 4) & 20 & 3 & 100 & 100 & 50 & 2 \\
\hline Stream & 1) & $0.40-2.40$ & $0.01-1.0$ & $10-160$ & $15-600$ & $10-590$ & $0.01-10$ \\
\hline sediments & 2) & 1.2 & 0.03 & 70 & 68 & 85 & 1.10 \\
\hline (ppm) & & 0.8 & 0.02 & 35 & 120 & 200 & 2.5 \\
\hline $\mathrm{N}=50$ & & No data & No data & No data & No data & No data & No data \\
\hline Mine & 1) & $1-70$ & $0.03-1.40$ & $15-660$ & $10-1500$ & $10-570$ & $0.3-31$ \\
\hline tailings & 2) & 5.2 & 0.26 & 270 & 455 & 275 & 8.7 \\
\hline$(\mathrm{ppm})$ & 3) & 6.5 & 0.5 & 246 & 600 & 235 & 13 \\
\hline $\mathrm{N}=3.5$ & 4) & 20 & No data & No data & No data & No data & No data \\
\hline Water & 1) & $0.03-2.1$ & $0.01-0.12$ & $0.14-3.40$ & $10-60$ & $0.3-1.2$ & $0.12-0.60$ \\
\hline$(\mathrm{ppb})$ & 2) & 0.44 & 0.03 & 1.4 & 30 & 0.5 & 0.25 \\
\hline \multirow[t]{2}{*}{$N=45$} & 3) & 0.45 & 0.30 & 1.6 & 33 & 0.3 & 0.11 \\
\hline & 4) & 10 & 3 & 30 & 50 & 10 & 1 \\
\hline
\end{tabular}

$\mathrm{N}=$ Number of samples analysed 


\section{DISCUSSION}

The high concentrations of arsenic (As) were encountered only in the mine tailing samples from Ntumbi (70 ppm As versus WHO (1993) permissible level of $20 \mathrm{ppm} \mathrm{As}$ ), Saza (47 ppm As) and Luika (36 ppm As). The high content of As in the mine tailings might have originated from the decomposition of accessory As-bearing minerals such as arsenopyrite (FeAsS), enargite $\left(\mathrm{Cu}_{3} \mathrm{AsS}_{4}\right)$ and tennantite $\left(\mathrm{Cu}_{12} \mathrm{As}_{4} \mathrm{~S}_{13}\right)$ that are found in trace amounts in the gold ores. Some As could have been introduced through As-based mineral flotation reagents during concentration of sulphide-hosted gold ore. The low content of As in water and stream sediments was due to the low mobility of the element in natural water systems since the element is readily scavenged by iron oxides after being released from the host ore minerals during weathering processes. Besides mining activities other anthropogenic sources of As might include alloys, storage batteries, agricultural herbicides and wood preservatives.

The concentration of cadmium in all sampled media was very low, reflecting the low content of sphalerite (in which $\mathrm{Cd}$ replaces $\mathrm{Zn}$ ) in the gold ores. This implies that derivation of $\mathrm{Cd}$ from other sources including electroplating, anticorrosive coating, PVC stabilizers, Ni-Cd batteries and alloys in the LGF was minimal.

The concentration of chromium in some soils, stream sediments and mine tailings was higher possibly owing to the $\mathrm{Cr}$ released from weathering of mafic-ultramafic wall-rocks (gabbro, basalts and pyroxenites) that host goldquartz veins in the LGF. In weathering regimes, $\mathrm{Cr}$ follows $\mathrm{Fe}$ and $\mathrm{Al}$ and is enriched in residual sediments like laterites and clays. Anthropogenic sources of $\mathrm{Cr}$ such as decomposition of alloys, refractories, paints and textile dyes, could be responsible for the observed high $\mathrm{Cr}$ concentrations in some media.

Few stream sediments and mine tailing samples have high concentrations of copper (up to $600 \mathrm{ppm}$ and $1500 \mathrm{ppm}$, respectively) that appear to have been derived from the breakdown of chalcopyrite and bornite found in the goldquartz veins. It is important to note that chalcopyrite was the second most abundant ore mineral in the gold-quartz veins in the LGF after pyrite. The low content of $\mathrm{Cu}$ in waters (mean $=30 \mathrm{ppb} \mathrm{Cu}$ versus $\mathrm{WHO}$ (1993) permissible level of $50 \mathrm{ppb} \mathrm{Cu}$ ) can be explained by the low mobility of the element in near neutral to alkaline $\mathrm{pH}$ conditions (6.5-8.5) prevailing in the waters of the LGF. In weathering conditions, $\mathrm{Cu}$ is highly mobile at $\mathrm{pH}$ below 5.5 but has low mobility at neutral or alkaline conditions (Reedman 1979).

The high concentration of total mercury in the stream sediments and mine tailings was mostly caused by anthropogenic $\mathrm{Hg}$ introduced to the environment by artisanal and small-scale miners during amalgamation and firing of $\mathrm{Au}-\mathrm{Hg}$ amalgam. Mercury is extensively used during gold extraction in the LGF. On average one gram of gold would require 2-3 grams of 
mercury during amalgamation. After amalgamation, mercury is evaporated to the atmosphere during amalgam burning to recover gold. Mercury spillage into the stream water is common during amalgamation. Water contains low concentrations of $\mathrm{Hg}$ owing the low $\mathrm{Hg}$ solubility and high density that makes it sink into the stream sediments.

Mine tailings and few stream sediments contained high concentrations of $\mathrm{Pb}$. The $\mathrm{Pb}$ was probably derived from weathering of accessory galena, which was third most abundant ore mineral in the gold bearing quartz-veins in the LGF. $\mathrm{Pb}$ could also have arisen from leaching of anglesite and cerussite. Other anthropogenic sources of $\mathrm{Pb}$ such as weathering of battery scraps, lead pipes, lead pigments and dispersion from gasoline emissions as well as applications of phosphate and sulphate fertilizers probably contributed to the observed high $\mathrm{Pb}$ concentrations in some soil samples (up to $80 \mathrm{ppm}$ versus WHO (1993) permissible level of $20 \mathrm{ppm} \mathrm{Pb}$ ), stream sediments (up to $590 \mathrm{ppm} \mathrm{Pb}$ ) and tailings (up to $570 \mathrm{ppm} \mathrm{Pb}$ ).

Mercury occurs in the ecosystem in different compound forms that have different solubility and different degrees of toxicity to organisms. Methylmercury $\left(\mathrm{CH}_{3} \mathrm{Hg}^{+}\right)$, which can form in aquatic environments, is an extremely toxic compound (Nakamura et cl. 1988, Meili 1991). Health effects related to the intake of methylmercury include brain damage, abnormal movement and reflexes, tubular nephrosis, stomatites, bronchial effects, spontaneous abortion and deformed brain and body. It has been related to minumata disease in Japan. Lead has no known biological role and is toxic, teratogenic and carcinogenic. In biological processes it has a detrimental effect through replacing calcium and iron in organisms (Koljonen 1992). Intake of $\mathrm{Pb}$ in human beings causes anaemia, neurological dysfunction, renal impairment and irreversible brain damage especially in foetusses, infants and children.

\section{CONCLUSION}

The levels of heavy metal concentrations in soils, stream sediments and mine tailings obtained during this study are of interest with respect to the health of people living in the LGF and the surrounding areas. Further studies that involve sampling and analysis of biological samples such as human hair and urine, fish, meat, vegetation and fruits for the determination of speciation of $\mathrm{Hg}, \mathrm{As}$, and $\mathrm{Pb}$ will be required to determine possible health risks and their bio-availability through the food chain.

\section{ACKNOWLEDGEMENT}

The author acknowledges the research grant by SIDA-SAREC on environmental impacts of mining and industrialization in Tanzania. I am also indebted to the whole research team from the Department of Geology, University of Dar es Salaam including Prof. J. Ikingura, Prof. M. 
Mutakyahwa, Dr. J. Kahatano, Dr. C. Kinabo and Dr. C. Kaaya for assisting during the fieldwork and writing of the report to SIDA-SAREC. The author also acknowledges Mr. R. Uhrberg of the Me-Ana Konsult Laboratory, Uppsala, Sweden, for his good guidance during sample preparations and analyses.

\section{REFERENCES}

Anon 1993 Guidelines for drinking-water quality. WHO, $2^{\text {nd }}$ ed., Vol. 1. Recommendations. Geneva

Aswathanarayana U 1995 Geoenvironment. A. A. Balkema, Rotterdam.

Berkman DA and Ryall WR (eds) 1982 Field geologists' manual, $2^{\text {nd }}$ edition. The Australasian Institute of Mining and Metallurgy, Monograph Series No. 9, Victoria, Australia.

Hamlin SN 1989 Preservation of samples for dissolved mercury. Water Resources Bulletin. 25: 255-262

Hopps HC, Angino EE, Banta JE, Beeson KE, Horvath DJ, Janda R, Everret AJ, Tardiff R and Underwood EJ 1974 Overview: Geochemistry and Environment, Vol. 1.: The relation of selected trace elements to health and diseases. National Academy of Sciences, Washington, D.C.

Kauranne K and Silanpää M 1992 Chemical elements in living organisms and industry. In: Kolyjonen $\mathrm{T}$ (ed.) The Geochemical Atlas of Finland, Part 2 TILL. Geol. Surv. Finland

Koljonen T 1992 The Geochemical Atlas of Finland, Part 2 TILL. Geol Surv. Finland, Espoo

Meili M 1991 Mercury in Boreal Forest Lake Ecosystems. Acta Universitisupsaliensis, Faculty of Science, University of Uppsala, Sweden

Mnali SR 1999 Palaeoproterozoic felsic magmatism and asscociated goldquartz vein mineralization in the western part of the Lupa Gold field, south-western Tanzania. Ph.D. thesis, University of Dar es Salaam

Nakamura K, Sakata T and Nakahara H 1988 Volatilization of mercury compounds by methylmercury-volatilizing bacteria in Minamata Bay Sediment. Bull. Environ. Contam. Toxicol. 41: 651-656

Reedman JH 1979 Techniques in mineral exploration. Applied Science Publishers

Uhrberg R 1982 Acid digestion bomb for biological samples. Analytical Chemistry 54: 1906-1908 